\title{
The Odd and the Ordinary: Haiti, the Caribbean and the World'
}

\author{
Michel-Rolph Trouillot (1949-2012)' \\ 'University of Chicago, United States
}

How does one explain Haiti? What is Haiti? Haiti is the eldest daughter of France and Africa. It is a place of beauty, romance, mystery, kindness, humor, selfishness, betrayal, cruelty, bloodshed, hunger and poverty. It is a closed and withdrawn society whose apartness, unlike any other in New World, rejects its European roots".

Nice passage, isn't it? Well, those of you who know my work may have guessed that I am trying to trick you. These words are not mine. They constitute the very first paragraph of Written in Blood, a sensationalist account of Haitian history written by Marine Colonel Robert Heinl and his wife Nancy ${ }^{2}$. I quote this paragraph in lieu of an introduction because it typifies a viewpoint widely shared in Haitian studies, one that I wish to challenge, namely the fiction of Haiti's exceptionalism. Heinl and Heinl start with a question: "How does one explain Haiti?" The question is then set aside for a laundry list of particulars. Then, at the end of the list, the emphasis shifts to Haiti's apartness: Haiti is unique. It is unlike any other country in the New World. And indeed, if we keep reading the next 700 pages, we soon discover that it is unlike any other country - period.

The notion of Haitian exceptionalism permeates both the academic and popular literature on Haiti under different guises and with different degrees of candidness. At first glance, this insistence on Haiti's special status seems to be a simple acknowledgement of the country's admittedly spectacular trajectory. I suggest, however, that there are hidden agendas - intellectual and political - behind this insistence, and that these agendas, rather than genuine interest in the particulars of Haitian history, underpin Haitian exceptionalism.

Haiti is unique. Haiti is different. Haiti is special. At a superficial level, these sayings could simply mean that a particular set of environmental, historical, and social features contribute in varied ways to make Haiti quite different from other places: that Haiti is not Argentina, or Canada, or Germany, or Senegal. I have absolutely no quarrel with such a statement. I can assure you that no one born in Aquín, Gonaïves, or Cité Soleil thinks of them as Buenos Aires, Frankfurt, or Dakar.

But those who insist most often on Haiti's uniqueness do not simply mean that Haiti is easily unique. For each and every society is unique, distinguishable from each and every other society. Indeed, regions within the same country can be distinguishable from other regions. Societies, countries, or regions are historical products and all historical products are unique - by definition and by necessity. And the more we know a place or a person, the more this place or this person appears unique. But we do not keep on repeating it: life is too short for that. To my knowledge, foreign or native writers who write about, say, the Dominican Republic, Paraguay, Bolivia, Thailand, Madagascar, or Gabon - to cite only a few remarkable places - do not go on repeating ad nauseam how quite unique these societies are.

\footnotetext{
1 This text was first prepared as the keynote address at a conference on "Haiti in Comparative Perspective", sponsored by Columbia/The New York University Consortium on Latin American and Caribbean Studies, New York University, New York, 9 February 199o. It is reproduced here with minor modifications. I thank Susan Lowes for valuable editorial suggestions. Editor's note: We have updated the Haitian Creole terms that Trouillot used to follow the contemporary orthography. We have also added the complete reference for one of his works (Trouillot, 1992) that had not yet been published at the time the original version came out. Finally, we would like to thank Michel-Rolph Trouillot's wife, Anne Carine Trouillot, who kindly authorized the republication and translation of this article into Portuguese.

2 The Heiln lived in Haiti the 196os, when the Colonel acted as an advisor to François Duvalier's regime. For the introductory passage, see Heinl and Heinl (1978, p. 1).
} 
They assume this uniqueness and proceed from there. So the celebrated uniqueness of Haitian society and culture must mean more than the distinctiveness that characterizes any historical product from any other historical products.

If all historical products are unique, not all of them are distinguishable in the same way. It is quite probable that a particular configuration of circumstances will lead to a historical product of which the uniqueness is dazzling: an individual, a group of individuals, an institution, or a phenomenon that strikes us more than otherwise similar entities. In short, some historical products are more remarkable than others, at least to certain groups of observers. However unique we may all be, it makes sense to insist that Julius Caesar, Napoleon, Shaka the Zulu, Toussaint Louverture, François Duvalier, or Mikhail Gorbachev are unique un ways that need to be noticed. It makes sense to insist upon the fact that the Holy See is a unique religious institution. That the French Academy is a unique combination of culture and politics. That German fascism was a unique political movement. That the state of Israel is a unique geopolitical entity. That the United States, Cuba, Brazil, Liberia, Tibet, or the Philippines are quite distinguishable countries, the uniqueness of which both strikes out and needs to be emphasized in the context of their own immediate environment or even perhaps in the context of world history.

In that sense, of course, Haiti seems more unique than many other countries. The list of features that makes is special is long, starting with the history of Saint-Domingue and the Haitian Revolution: first and only successful slave revolution in modern history. First independent country of Americas, and for a long time the only one, where freedom meant freedom for everyone. First and for a long time sole black republic in world history, indeed, the first nonwhite modern state. The most peasant country of the Americas. Largest creole speaking population of the world. And so on. And so on. And so on.

In that sense, of course, Haiti is indeed unique. And if we want to play semantic games, it is not just unique: it is exceptional, the result of a striking convergence of historical particulars. This is the distinctiveness that accounts for Haiti's cultural resilience. This is the distinctiveness that attracts many foreigners - tourists and academics, for good or for bad. This is the distinctiveness that succors Haitian national pride - for good and for bad. This is the distinctiveness that Haitian tourism officials have banked on for more than twenty years with the slogan "Vive la différénce!"

I have no quarrel with such a view of Haiti's particularisms, even though I may question the use some make of them. For all the reasons I have mentioned, and probably many more, Haiti is in many ways exceptional. I would insist though, that this exceptionalism is only one way to look at Haitian reality. There are much less petulant continuities embedded in this spectacular trajectory. The majority of Haitians live quite ordinary lives. They eat what is for them - and for many others - quite ordinary food. They die quite ordinary deaths from quite ordinary accidents, quite ordinary tortures, quite ordinary diseases. Accidents so ordinary that they could be prevented. Tortures so ordinary that the international press does not even mention them. Diseases so ordinary that they are easily treated almost anywhere else. Exceptional, is it?

Certainly more exceptional than India, Java, Burma, or Ethiopia - which are of course exceptional in their own way. Listen to Blair Niles, the author of Black Haiti: "I am familiar with the measured posturing dances of Japan, of India, Java and Burma. I have watched the head-hunting dance of Dyaks of Borneo. That was savage enough; primitive enough...But savage as it was, that too had been in a way sophisticated". For Blair Niles discovered Haiti and its dances. That, says Niles, "went further back than the hunt [of Borneo]; back to the beginning...” (Niles, 1926, p. 27).

Note that Blair Niles is writing in admiration, in this passage at least. Elsewhere in the book, he heavily criticizes foreigners who denigrate the Haitian people. Further, there is ample evidence throughout the text that Niles made a more genuine effort than many other visitors, both before and after him, to understand Haiti. At any rate, no one can accuse him of disliking Haitians. Quite the opposite: he is attracted to them. 
But he is attracted to them the way one can be attracted to a sexual fetish or a taboo. That is, he is attracted to Haiti as deviance. What he likes in Haiti is what he finds aberrant, the reverse image of a world of normalcy. That is not unique. That is not even exceptional. That is weird.

Listen to Professor Heinz Lehman of McGill University talking to student Wade Davis of Serpent and Rainbow fame: "Let me relieve you of any further suspense, Mr. Davos. We understand... that you are attracted to unusual places. We propose to send you to the frontier of death" (Davies 1985: 15). Davis is attracted to "unusual" places. Unusual here does not mean unique, and the reference to the frontier of death as well (as the Hollywood version of the book) is there to testify to the nuance. No, unusual here means odd, strange, peculiar, freakish, queer, bizarre. Weird, indeed, don't you think?

To be sure, Davis is careful not to use these words; but that may be a reflection of the times. Even travel guides and National Geographic have learned not to present so-called exotic places in explicitly condescending or derogatory terminology. Further, since the nineteenth century, a Haitian tradition of sharp rebuttal has kept many foreign writers, French and North American in particular, on their guard. Thus, for instance, Davis - of all people! - tries to distance himself from "sensational films and pulp fiction" (1988: 3 ). The Heinls (one of whom epitomized the worst of U.S. interference in Haitian politics) dedicate their book to Haitian nationalist heroes. It has become stylish for foreign writers to denounce Haiti's bad press while contributing to it in fact.

In that context, Haitian exceptionalism tends to function at the level of the subtext in most books published outside the country in the second half of this century. While it permeates the entire work, there are very few sentences that actually articulate it, except perhaps on the back cover or in the ad copy (e.g.; Davis, 1985; Abbott, 1989). ${ }^{3}$ At times, however, writers - including respected academics - can be less careful, or nonchalant enough for Haitian exceptionalism to appear clearly in the text. One more quote among many: "Haiti, like eighteenthcentury Sicily has always been a place apart," a place with "a penchant for the bizarre and the grotesque" (Rotberg, 1971, pp. 7-8). As the French used to put it, with debonair condescension, "Singulier petit pays".

I am, of course, bothered by this condescension. But there is more to it. The most important problem with the overemphasis on Haiti's singularity - even if not phrased in derogatory terms - is both methodological and political. My own intolerance is less toward the narrow-mindedness often implicit in such statements (which, after all say more about their authors than about Haiti) than toward the practical consequences of this narrow-mindedness. When we are being told over and over again that Haiti is unique, bizarre, unnatural, odd, queer, freakish, or grotesque, we are also being told, in varying degrees, that it is unnatural, erratic, and therefore unexplainable. We are being told that Haiti is so special that modes of investigation applicable to other societies are not relevant here.

In her remarkable book, Haiti and the Great Powers, Brenda Gayle Plummer criticizes the myth of Haitian exceptionalism and exposes some of its consequences. In Plummer's view, "The idea that Haiti could fit no paradigm prohibited the development of any but most conservative policies" on the part of international powers, including the United States (Plummer, 1988). One could add that the very same view continues today to influence some policy-makers in the United States, in France or in the Vatican - to cite only three states involved in Haitian affairs. Plummer is much more indulgent than I am, however, toward Haitian politicians and intellectuals, even though she admits that they share some of the blame. In my view, in both cases Haitian exceptionalism acts as a shield.

\footnotetext{
3 Publishers and reviewers are less cautious and more candid than writers themselves. So, Warner Books presents Davis's The Serpent and the Rainbow as a "journey of discovery across the border between life and death, between good and evil". The back cover of the paperback edition of the same book quotes reviews from the Wall Street Journal and the Washington Post: "Exotic and far-reaching... just the way Indiana Jones would tell it... Replete with bizarre details to titillate the curious..." (Davis, 1985).
} 
Though not the privy of non-native writes, the fiction that Haiti escapes analysis and comparison emerged out of the minds of European and North American observers, mostly white males, who wrote about Haiti in the early nineteenth century, at the time when the very existence of a "black" state that had issued from an anticolonial revolution appeared to them as an aberration. For a plethora of writers from James Franklin to Gustave d'Alaux, to Spencer St. John to Robert and Nancy Heinl, Haitian exceptionalism has been a shield that masks the negative contribution of the Western powers to the Haitian situation. Haitian exceptionalism functions as a shield to Haiti's integration into a world dominated by Christianity, capitalism, and whiteness. The more Haiti appears weird, the easier it is to forget that it represents the longest neocolonial experiment in the history of the West.

Even James Leyburn was guilty of the same sin of omission. In the third chapter of his important book, The Haitian People, Leyburn (1941, p. 32) wrote: "if ever a country had an opportunity to start absolutely fresh in choosing its own social institutions, Haiti had that opportunity in 1804... The Haitians might (theoretically, at least) have invented an entire new little world of economic, political, religious, and social life. All paths were open to them". Leyburn concluded that unfortunately Dessalines's mental limitations set the Haitians on the road to disaster.

Well, that won't do. Neither theoretically nor in practice. With one stroke of the pen, Leyburn erases three centuries of direct colonial domination and a century and a half of neocolonialism. And this from an author who remains, in my view, one of the best observers, foreign or Haitian, of Haitian society and culture.

The Haitian side is no more glorious, even though at times it looks better on paper. Indeed, many Haitian intellectuals and politicians continue to repeat the same nonsense, more loudly even than their foreign counterparts. The reality is that fiction is as convenient to the Haitian elites as it is to many foreigners, even though for different reasons.

Before the twentieth century, Haitian writers rarely if ever promoted Haitian singularity in their studies of Haitian reality. In fact, quite the opposite, especially for the early part of the nineteenth century. Indeed, Haitian intellectuals rightly saw the theories of Haitian exceptionalism that were spreading in Europe and North America as implicitly - and often explicitly - racist. In the immediate aftermath of independence, a writer such as Baron de Vastey relied on the universalist principles of the Enlightenment to herald the Haitian Revolution and reject theories associating physical appearance and national character. ${ }^{4}$ In the late nineteenth and early twentieth centuries, writers such as Demesvar Delorme, Louis-Joseph Janvier, Anténor Firmin, Edmond Paul, down to Jean Price-Mars and Dantès Bellegarde tried in varying degrees to make sense of Haiti in an international context, and to apply some of the prevalent theories of their times to the Haitian situation. This is particularly true in the social sciences and economics. However much one may now question the economic liberalism of an Edmond Paul, the sociology of Louis-Joseph Janvier, or the ethnology of Jean Price-Mars, these authors did not think that Haiti escaped the paradigms of their times.

But even as these writers quoted famous European thinkers, political practice in Haiti fed on exceptionalism. The Haitian elites acted as if, theories aside, Haiti was exceptional and should therefore be led in an exceptional manner. Thus the politics of a Delorme or a Firmin were not that much different from the illiterate generals who supported or opposed them and may have believed in Haitian exceptionalism. Still, the public and unchallenged assumption, in all intellectual circles, that Haiti was indeed a country like any other limited the damages inflicted by the pragmatic acceptance of practices otherwise deemed unconventional.

With the 1915-1934 U.S. occupation, however, Haitian studies took a sharp turn for the worse with increasing acceptance of theories based on Haiti's apartness. The occupation had led to a reevaluation of Haitian identity among the elites, including from writers such as Jean Price-Mars. But the ideological malaise of the times also

4 At the same time, yet in a more subtle way, Haitian poets and, later, novelists, replied to the negative mythification of Haitians by the West with mythmaking writings of their own, a process that continues today (e.g. Dash 1988). 
opened the door to a possible questioning of the universals inherited from the Enlightenment. Drawing from Price-Mars but rejecting his Enlightenment heritage, the Griot school in particular - one member of which was François Duvalier - insisted on the particularities of the Haitian mentalités.

From the 1930s on, research, political practice and legislation emphasized Haiti's singularity, and indeed helped to increase this singularity with such aberrations as the infamous anti-Communist law of 1969. Among the many reasons cited for forbidding even the belief in Communism, the law notes "the incompatibility of imported doctrines, notably Marxism-Leninism, with the social, political, and economic order of Haiti" (cited in Trouillot and Pascal-Trouillot, 1978, p. 445; emphasis added). According to Duvalier, Haiti could draw its ingredients for progress only from its own culture, a culture that is, of course, unique in the almost mystical sense emphasized by the Griot doctrine ${ }^{6}$.

I would be the last to say that Haitian culture is not unique, or that Haiti should not use its cultural resources. The point is that before and during the Duvalier years, the particularities of Haiti were used to shield the Haitian elites. Haiti is unique; therefore, it evades foreign theories, including class analysis. Indeed, it evades all analysis in the strict sense of the term. It also evades comparison. Therefore, we can rule this country in ways that seem to defy the imagination of most foreigners and quite a few Haitians. Haiti is especial; thus it deserves custom-made institutions and a custom-made government. The political maneuver is obvious. So is the intellectual fallacy upon which it rests.

It seems to me that we learn much less about Haiti if we read it as an aberration that defies any explanation than if we learn to place it in a comparative framework. One of the most serious limitations of Haitian studies, in Haiti and elsewhere, comes from the propensity of Haitianists, and especially of Haitian-born scholars, to study Haiti and nothing but Haiti. The assumption is that nothing we learn from looking at another society can teach us anything about Haiti, since Haiti is so unique. To be sure, insularism is a feature of Caribbean studies. Jamaicans study Jamaica, Cubans study Cuba, and few foreigners spread their wings over linguistic boundaries within the archipelago. Yet the irony in this case is that Haiti's exceptional history provides so many features that can benefit from the observation of other societies, especially in Latin America and more particularly in the other Antilles.

In the little space remaining, I will only mention a few of the areas where Haitian studies can surely benefit from the light of neighboring cases. I rest on the shoulders of so many colleagues that I cannot mention them all. Nor can I cover all the potential areas for comparative research.

The peasantry is one such area, and an important one. I spent fifteen months doing fieldwork among the peasantry of Dominica, and I believe that I learned much more about the Haitian peasantry during those months than I did during eighteen years in Port-au-Prince. Haiti, like the Windward Islands, like Jamaica, like Puerto Rico or to a lesser extent like Trinidad and Tobago, has a substantial postplantation peasantry. How do theories of the impact of the plantation economy or on the passage from plantation to peasantry in a context dominated by capitalism (Trouillot, 1988) fit the Haitian case? To my knowledge Alex Dupuy may be the first Haitian scholar to have tackled this question head on.

\footnotetext{
5 Because members of the Griot school claimed to be followers of Jean Price-Mars, Price-Mars has passed for a proponent of Haitian exceptionalism, a charge for which I find no justification in his voluminous writings. Price-Mars (1929) certainly did not at the outset reject what he took for science, not even Justin Dévot's unsuccessful tentative effort to introduce positivism in Haiti. Rather, in a move that anticipated both Bastide and Herskovits, Price-Mars simply insisted that Haiti could not be studied as if it were an avatar of Europe with no African influence, and that Haiti's African heritage was itself amenable to scientific study. Both points are now unquestioned among anthropologists, although they may derive from them quite different conclusions. That the first point was also repeated by Duvalier as a part of a new problématique (Denis and Duvalier, 1936) does not make Price-Mars an exceptionalist. At any rate, in Price-Mars's own words, his seminal Ainsi parla l'oncle (1928) is "an endeavor to integrate the popular Haitian thought into the discipline of traditional ethnography (Price-Mars 1983: 7).

6 Two preceding laws on Communist activities under Presidents Estimé (February 1948) and Magloire (September 1951) make no reference to Haitian culture as such (Trouillot and Pascal-Trouillot, 1978, p. 443-44).
} 
Haitian studies in general would benefit from a more systematic reading of Walter Rodney, George Beckford, Raymond Smith, and J.R. Mandle. Sidney Mintz's comparative essays on Caribbean peasantries $(1979,1990)$ would serve as an excellent starting point for such research.

There are so many questions left unanswered in Caribbean studies that have a direct impact on the way Haitianists could look at Haiti that I can only start such a list. Why are mating patterns similar to Haitian plasaj, or rural institutions similar to the Haitian lakou or the konbit present elsewhere in the Caribbean? How far do these similarities go? Are they surviving or disappearing at the same rate? For the same reasons? How do these tie in with gender? Market women in Haiti are strikingly similar to market women in Jamaica - or in Ghana, for that matter. Why? How far into social roles can we carry the post-plantation paradigm, Mintz's reconstituted peasantry?

Just as there is a post-plantation peasantry, there may also be a post-plantation state. My own comparison of the post-slavery elites of Dominica and Haiti reveals striking similarities. It is no accident that one of the most important slogans of nineteenth century Haiti - "Le plus grand bien au plus grand nombre" ("The greatest good to the greatest number") - was the slogan of the mulatto elite in British-dominated Dominica, but it was the leitmotif of the darker Parti National in mulatto-dominated Haiti (Trouillot, 1992). Does the post-plantation situation lead to specific forms of state power, including specific forms of state rhetoric (Trouillot, 1990)?

One could tie to that issue matters well debated in Latin American studies, such as authoritarianism and the role of the military. Is there such a thing as a social authoritarianism that can effect forms of political power? The Haitian army, just like the army in Panama, just like the army in the Dominican Republic, just like - until recently - the army in Nicaragua, is the product of a U.S. invasion. What are the similarities and the differences between these institutions as they function in societies admittedly different but also in many ways similar?

Religion is another domain. To my knowledge, no one has yet systematically picked up the trail opened by Roger Bastide in his sketchy comparisons of Brazil and Haiti. There is also a trail to pick up in the work of Melville Herskovits on Africanisms - with the necessary corrections, of course, but also with a much needed rereading of Price-Mars. Now that we know more about, say, both Suriname and Brazil, how "African" does Haiti appear in the hemispheric perspective? And of course we could push the comparison all the way to Africa.

And similarly we should look at Haitian creole in the light of what we now know about creole languages as far away as Réunion. At the very least, Haitian creole studies would benefit much from greater familiarity with such works as that of Louis-Félix Prudent on Guadeloupe-Martinique, and especially the writings of Marvyn Alleyne on St. Lucian creole and other Afro-American languages. And I have still not said anything about music...

I have scratched the tip of the iceberg to make a more general point. Haitian studies has experienced a small but noticeable revival since the late 197os. But there is more to do. Much more. There are threads to pick up, new connections to be made. One would hope that, when overemphasis on Duvalierism - if not on state politics - quiets down, practicing Haitianists will seriously start reading not only Bellegarde and Price-Mars (whom I consider to be the last of an intellectual lineage) but their precursors, the classics of nineteenthcentury Haitian social thought?. In fact, all aspects of nineteenth-century life in Haiti will benefit from serious attention, since nineteenth-century studies have been unjustly outflanked by the dual emphasis on the slave revolution of 1791 and on twentieth-century politics. I emphasize social thought simply because the writers of that era, with their faith in universals and their desire to defend Haiti in a context of open ostracism, may have given us the most potent antidote to the myth of Haitian exceptionalism: specific questions, tuned to Haitian particulars but informed by international debates of the times.

\footnotetext{
A good deal of this corpus is available. Further, publisher Henri Deschamps has recently issued the entire work - including hitherto unpublished volumes - of Thomas Madiou, Haiti's first comprehensive historian.
} 
For Haitian studies cannot proceed without making a theoretical leap. Quite simply, we need to drop the fiction, inherited from the nineteenth-century racist literature, that Haiti is unique - if by unique one means that it escapes analyses and comparison. Haiti is not that weird. It is the fiction of Haitian exceptionalism that is weird.

\section{References}

ABBOT, Elizabeth. 1988. Haiti. New York: McGraw Hill.

DASH, J. Michael. 1988. Haiti and the United States: Stereotypes and the Literary Imagination. London: Macmillan.

DAVIS, Wade. 1985. The Serpent and the Rainbow. New York: Warner Books.

HEINL, Robert Debs; N. Heinl. 1978. Written in Blood. The Story of the Haitian People, 1492-1971. Boston: Hough ton Mifflin.

LEYBURN, James. 1941. The Haitian People. New Haven: Yale University Press.

MINTZ, Sidney W. 1989 [1974]. Caribbean Transformations. New York: Columbia University Press.

MORAL, Paul. Le Paysan haïtien. Étude sur la vie rural en Haïti. Paris: Maisonneuve Larose.

NILES, Blair. 1926. Black Haiti: A Biography of Africa's Eldest Daughter. New York: Grosset and Dunlap.

PLUMMER, Brenda Gayle. 1988. Haiti and the Great Powers. Baton Rouge: University of Louisiana Press. PRICE-MARS, Jean. 1929. Une étape de l'évolution haïtienne. Port-au-Prince: Imprimerie de la Presse. . 1983 [1928] So Spoke the Uncle. Washington, D.C.: Three Continents Press.

ROTBERG, Robert; Christopher C. Clague. 1971. Haiti: The Politics of Squalor. Boston: Houghton Mifflin. TROUILLOT, Ernest; Ertha Pascal-Trouillot. 1978. Codes de lois usuelles. Port-au-Prince : Editions Henri Deschamps.

TROUILLOT, Michel-Rolph. 1988. Peasants and Capital: Dominica in the World Economy. Baltimore: The Johns Hopkins University Press. . 1990. Haiti, State against Nation: The Origins and Legacy of Duvalierism. New York: Monthly Review Press.

. 1992. "The Inconvenience of Freedom: Free People of Color and the Aftermath of Slavery in Dominica and Saint-Domingue/Haiti". In: DRESCHER, S. F. McGlynn (eds.). The Meaning of Freedom: Economics, Politics and Culture after Slavery. Pittsburgh: University of Pittsburgh Press, pp. 147-182. 